\title{
Production of two species of interferon by Large White and Meishan pig conceptuses during the peri-attachment period
}

\author{
C. La Bonnardière*, F. Martinat-Botte†, M. Terqui†, F. Lefèvre*, \\ K. Zouari $\ddagger$ J. Martal $\ddagger$ and F. W. Bazer§ \\ *I.N.R.A., Laboratoire de Virologie et d'Immunologie Moléculaires, Centre de Jouy, \\ 78350 Jouy-en-Josas, France; †I.N.R.A., Station de Physiologie de la Reproduction, \\ Centre de Tours, 37380 Monnaie, France; $\ddagger$ I.N.R.A., Unité d'Endocrinologie de l'Embryon, \\ Centre de Jouy, 78350 Jouy-en-Josas, France; and §Department of Animal Science, \\ University of Florida, Gainesville, Florida 32611, USA
}

\begin{abstract}
Summary. Antiviral activities present in uterine flushings from pregnant Large White, Large White 'hyperprolific', and prolific Meishan gilts, between Days 8 and 20 of gestation were compared. Flushings $(20 \mathrm{ml})$ from all gilts between Days 14 and 20 were positive in an in-vitro interferon (IFN) assay using vesicular stomatitis virus as a challenge infection. Highest antiviral activities (of up to $400000-1200000$ total Units/ flushing) were obtained at Day 16 of gestation, i.e. clearly after the beginning of attachment. There was no major difference between breeds although, at Day 14, flushings from Meishan gilts yielded significantly higher titres than those from the other two, suggesting a correlation with the previously described earlier trophoblast elongation in Meishan gilts. Conceptus cultures contained antiviral activity, with values very close to those obtained in vivo, but the difference between breeds was not significant. Cultures from Day 20 on contained very little antiviral activity. The antiviral activity was associated with a mixture of at least two IFNs, one of which was IFN-alpha like, and the other was serologically identified as an IFN-gamma, that is an 'immune IFN', previously found to be secreted only by $T$ lymphocytes. This finding may have implications for our understanding of the immunology of early pregnancy.
\end{abstract}

Keywords: pig; conceptus; attachment; antiviral activity; immune interferon

\section{Introduction}

Pregnancy in mammals remains an immunological enigma, since the maternal tissues tolerate the semi-allograft constituted by the implanting conceptus. Successful immunization of women that experience repeated abortions with paternal antigens, and experimentation on in-bred lines of mice that habitually abort (Chaouat et al., 1983; Gill, 1983; Hunziker \& Wegmann, 1986), have provided an experimental basis for several theories of the immunology of gestation. One hypothesis (Hunziker \& Wegmann, 1986) states that a cascade of immune reactions, triggered by paternal antigens, favourably contributes to maternal tolerance of the fetus. Growing numbers of cytokines have been found in the reproductive tract during pregnancy in several animal species (Hunt, 1989), but their immune role(s) is not known.

An interferon-alpha (IFN- $\alpha$ ) with potent antiviral activity is secreted during the periimplantation period by sheep and cattle conceptuses. This IFN- $\alpha$, produced by the trophectoderm, is the same molecule as trophoblastin or ovine trophoblast protein-1 (oTP-1), a conceptus secretory protein previously shown to be antiluteolytic (Martal et al., 1979; Heyman et al., 1984; Bazer et al., 
1987; Helmer et al., 1988; Vallet et al., 1988; Pontzer et al., 1988). The identity between oTP-1 (or bTP-1) and IFN- $\alpha$, most probably IFN- $\alpha_{\mathrm{II}}$, is based upon clear-cut nucleotide and amino-acid sequence homologies (Imakawa et al., 1987; Charpigny et al., 1988; Stewart et al., 1989; Charlier et al., 1989; Imakawa et al., 1989). That the only identified role for a conceptus-derived cytokine is not immunological may seem paradoxical, but suggests that such a cytokine may have multiple biological effects.

In ruminants, maternal recognition of pregnancy (the maintenance of corpus luteum function) depends upon synthesis of specific proteins by the conceptus, but it has been reported that pig conceptus secretory proteins have no significant effect on CL lifespan in cyclic gilts (Harney \& Bazer, 1989). However, significant antiviral activity has been reported between Days 12 and 17 of gestation in uterine flushings of gilts and in pig conceptus-conditioned culture medium (Cross \& Roberts, 1989; Mirando et al., 1990). We have extended this study to include the comparison of 3 breeds of pigs, i.e. Large White controls, Large White hyperprolific (Large White ${ }^{\mathrm{H}}$ ), and Chinese Meishan. Meishan pigs are highly prolific. Therefore, study of relevant mechanism(s) could be valuable both for our understanding of the physiology and/or immunology of gestation, but also for future pig breeding improvement. Previous studies have indicated faster and more synchronous conceptus development between Days 8 and 14 in Meishan than in Large White gilts, and also higher embryo survival rates at Day 30 in Meishan gilts (Bazer et al., 1987). Comparative data concerning antiviral activy in Meishan and European breeds of pigs are not available. The present study was to quantify, as far as possible, time-dependent and breed-dependent levels of antiviral activity produced by pig conceptuses in early pregnancy, and to identify as far as possible the species of interferon(s) produced.

\section{Materials and Methods}

Animals. Data were obtained from 45 pregnant Meishan, 27 Large White and 33 Large White Hyperprolific (Large White ${ }^{\mathrm{H}}$ ) gilts. The Large White ${ }^{\mathrm{H}}$ genotype has been obtained by selection of sons of hyperprolific sows, on the basis of their prolificacy index. Large White ${ }^{\mathrm{H}}$ gilts are characterized by a higher ovulation rate, which is counterbalanced, at the first parity, by a high embryonic mortality (Bolet et al., 1986). All gilts had experienced 3 oestrous cycles before pregnancy. Detection of oestrus was made twice daily. Gilts were artificially inseminated with semen from boars of the same breed at 12 and $24 \mathrm{~h}$ after the onset of oestrous behaviour for both Large White and Large White ${ }^{\mathrm{H}}$ gilts, and 24 and $36 \mathrm{~h}$ for Meishan, since the interval between oestrus and ovulation is longer by about $10 \mathrm{~h}$ in Meishan females (Terqui et al., 1990). Day 0 of gestation was defined as the day of the first insemination. The fertility rates were $90 \%$ for Meishan gilts, and $78 \%$ for gilts of the two Large White genotypes.

Experimental design. In Exp. I, 52 gilts were assigned randomly on Days 8, 10,11, 12 and 14 of gestation (with at least 2 and at most 6 gilts per genotype per day). Antiviral activities were measured in the uterine flushings which were kept frozen at $-20^{\circ} \mathrm{C}$ for 6 months (Fig. 1). In Exp. II, data were obtained from 53 gilts: 48 were assigned randomly on Days 14, 16 and 20 of gestation for measuring antiviral activity in uterine flushings and in conceptus-conditioned culture medium ( $5 \pm 1$ gilts per genotype, per day). The antiviral assay was done within 2 weeks after sampling. In addition, 5 Meishan gilts were slaughtered on Days 17 (2), 19 (1), 22 (1) and 25 (1) of pregnancy for analysis of antiviral activity in conceptus culture medium.

Flushings. The reproductive tracts were obtained immediately after slaughter and put on ice until uterine horns were flushed as described previously (Geisert et al., 1982a). Each uterine horn was independently flushed with $20 \mathrm{ml}$ $0.9 \%(\mathrm{w} / \mathrm{v})$ saline. Resulting fluids were clarified by centrifugation at $1700 \mathrm{~g}$ for $10 \mathrm{~min}$. Supernatants were immediately frozen at $-20^{\circ} \mathrm{C}$ until assayed for antiviral activity. Average volumes of uterine flushings were $14 \pm 5 \mathrm{ml}$ per uterine horn on Days 14-16 (there was no significant difference between Days 14 and 16), and $23 \pm 8 \mathrm{ml}$ at Day 20 . On Day 20 of pregnancy, for the majority of gilts, it was impossible to recover implanted conceptuses by flushing; therefore the uterine horn was dissected to extract conceptuses. At Day 20, the numbers of conceptuses per gilt were counted but, for Days 8-16, the conceptuses were removed only after flushing the uterine horns.

Ovarian weight and the number of corpora lutea (CL) per ovary were determined. Lengths and weights of uteri were obtained after collecting uterine flushings. The width of one uterine horn, endometrial surface area and total endometrial weight were also measured as described previously (Bazer et al., 1988). Weights of the gilts were also recorded before slaughter.

Conceptus cultures. Conceptuses were collected on different days of gestation for assay of secretion of antiviral activity in culture. About $0.5 \mathrm{~g}$ conceptus (wet weight) was transferred to $90-\mathrm{cm}$ Petri dishes, in $12 \mathrm{ml}$ Menezo's B2 medium (A.P.I. Systemes, Montalieu, France) without bovine serum albumin, supplemented with $5 \mathrm{mg}$ glucose/ml, 
$0.2 \mathrm{IU}$ insulin $/ \mathrm{ml}, 0.05 \%$ polyvinyl-pyrrolidone $\left(M_{\mathrm{r}} 360000\right.$; Sigma, St Louis, MO, USA), $0.1 \mathrm{mg}$ aprotinin $/ \mathrm{ml}$, $100 \mathrm{IU}$ nystatin $/ \mathrm{ml}, 100 \mathrm{IU}$ penicillin $/ \mathrm{ml}$, and $10 \mu \mathrm{g}$ streptomycin $/ \mathrm{ml}$. Incubation was at $38^{\circ} \mathrm{C}$ in a controlled atmosphere of $5 \% \mathrm{CO}_{2}$-air mixture, with constant rocking. After a 24 -h incubation, supernatants were centrifuged at $5000 \mathrm{~g}$ for $5 \mathrm{~min}$, divided into aliquants, and stored at $-70^{\circ} \mathrm{C}$.

Antiviral activities in uterine flushings and in conceptus-conditioned culture medium were determined as previously described (La Bonnardière \& Laude, 1981). Briefly, monolayers of Madin-Darby Bovine Kidney (MDBK) cells in microtitration plates were incubated overnight with serial 3-fold dilutions of fluids under study and standard IFN, in Minimum Essential Medium (MEM) plus $5 \%$ fetal calf serum (FCS). Supernatants were then withdrawn, and cells infected with Vesicular Stomatitis Virus, serotype Indiana, in MEM $+2 \%$ FCS (multiplicity of infection: 1 Plaque Forming Unit per 50 cells). After a further 24-h incubation, cells were stained with a solution of $1 \%$ violet crystal in $1: 5$ ethanol/water $(\mathrm{v} / \mathrm{v})$, when control infected cell sheets were $100 \%$ lysed. End-point protective dilutions were scored, and titres were calibrated with a laboratory reference IFN included in each assay. This reference IFN was assigned a titre of 1000 International Units/ml after parallel titrations with reference Human Interferon Alpha (Ref. Ga23-902-530, NIH, Bethesda, MD, USA) on MDBK cells. Titres in flushings were expressed both in IU/ml (Fig. 1) and in total IU per uterine horn (Table 2, results from Exp. II). The latter figures were calculated, on Days 14 and 16, as titres in $\mathrm{IU} / \mathrm{ml} \times 20 \mathrm{ml}$, and on Day 20 as titres in IU $/ \mathrm{ml} \times 30 \mathrm{ml}$ (as volumes of Day-20 flushings are higher by 9-10 $\mathrm{ml}$, see above: 'Flushings'). Standard deviations of geometric means (arithmetic mean of $\mathrm{log} \mathrm{IU} / \mathrm{ml}$ ) were calculated using Student's table at the level 0.05.

Characterization of antiviral activity. For measuring IFN stability at acidic $\mathrm{pH}$, a pool of Day- 16 uterine flushings from Large White gilts was dialysed for $24 \mathrm{~h}$ against either PBS pH 7.4, or $0 \cdot 2 \mathrm{M}$-glycine- $\mathrm{HCl} \mathrm{pH} \mathrm{2 \cdot 0.} \mathrm{Residual} \mathrm{anti-}$ viral activity was determined as described above, in comparison with rPoIFN- $\alpha$ l and rPoIFN- $\gamma$ submitted to the same treatment. E. coli-derived pig IFN- $\gamma$ was a generous gift of Dr Martinod (Biovet-Ciba-Geigy, St Aubin, Switzerland).

The following cell lines and strains were used for measuring cross-species antiviral activity of uterine flushings and of conceptus culture medium. MM 10 (Muscle de Mouton) is a sheep cell line established at INRA (Jouy-en-Josas) from fetal lamb fibroblasts. RPa (Rein de Porc Adulte) is a strain of low passage, epithelial pig kidney cells isolated in the same laboratory from an adult pig, and was found, like other primary pig kidney cells, to be very susceptible to a direct toxic effect of IFN- $\alpha$ (Laude \& La Bonnardière, 1984). Human Placental WISH cells and mouse mammary L929 cells were purchased from ATCC (Rockville, MD, USA). All these cells were grown and maintained in MEM $+10 \%$ FCS.

Seroneutralization of IFN activity present in flushings from Large White gilts was assayed by a constant antibody method (Kawade \& Watanabe, 1984), in which 1:100 dilutions of antisera were applied to MDBK cells before serial 3fold dilutions of IFN. The extent of neutralization was measured by the $\log (\mathrm{IU} / \mathrm{ml})$ difference in activity between control flushings and the corresponding titre in the presence of antiserum. Sheep antiserum to human leucocyte IFN (natural IFN- $\alpha$ ) was a gift of C. Chany (INSERM, Hopital St Vincent-de-Paul, Paris, France). Rabbit antiserum to recombinant pig IFN- $\gamma$ was provided by B. Charley (Charley et al., 1988). Rabbit antiserum to oTP-1 was raised at INRA (Jouy-en-Josas) against trophoblastin purified by ion-exchange chromatography (Charpigny et al., 1988).

\section{Results}

\section{Ovulation rates and embryo survival}

Ovulation rates did not differ significantly between breeds and were $14 \cdot 6 \pm 2 \cdot 1$ (mean \pm s.d.) for Meishan, 15.8 \pm 2.0 for Large White, and $15 \cdot 8 \pm 2 \cdot 7$ for Large White ${ }^{\mathrm{H}}$ gilts.

On Day 20 of gestation, embryonic survival was higher $P<0.01)$ for Meishan $(80 \%)$ than Large White $(66 \%)$ and Large White ${ }^{\mathrm{H}}(54 \%)$ gilts. The length, weight and width of the uterine horns as well as total endometrial surface area and calculated weight were greater $(P<0.01)$ for Large White and Large White ${ }^{\mathrm{H}}$ gilts irrespective of day of gestation (data not shown).

\section{Antiviral activity in flushings}

Titres of IFN were measured in uterine flushings between Days 8 and 20 of gestation. Figure 1 shows time-dependent titres in uterine flushings from Meishan and Large White gilts obtained in Exps I and II. The duplication of Day-14 samples showed that samples from Exp. I had apparently lost much of their antiviral activity after 6 months. Titres became detectable on Day 12 for Meishan gilts, were maximum at Day 16, and progressively declined until Day 20 in the two breeds. The highest mean titres were obtained for Meishan gilts $(\mathrm{N}=5)$, i.e. $10^{4 \cdot 26}=14590 \mathrm{IU} / \mathrm{ml}$.

Only data from Exp. II for Days 14, 16 and 20 were sufficient for statistical analysis (Table 1). On Day 14, flushings from Meishan gilts contained more IFN than did those from Large White 
EXP.I

EXP. II

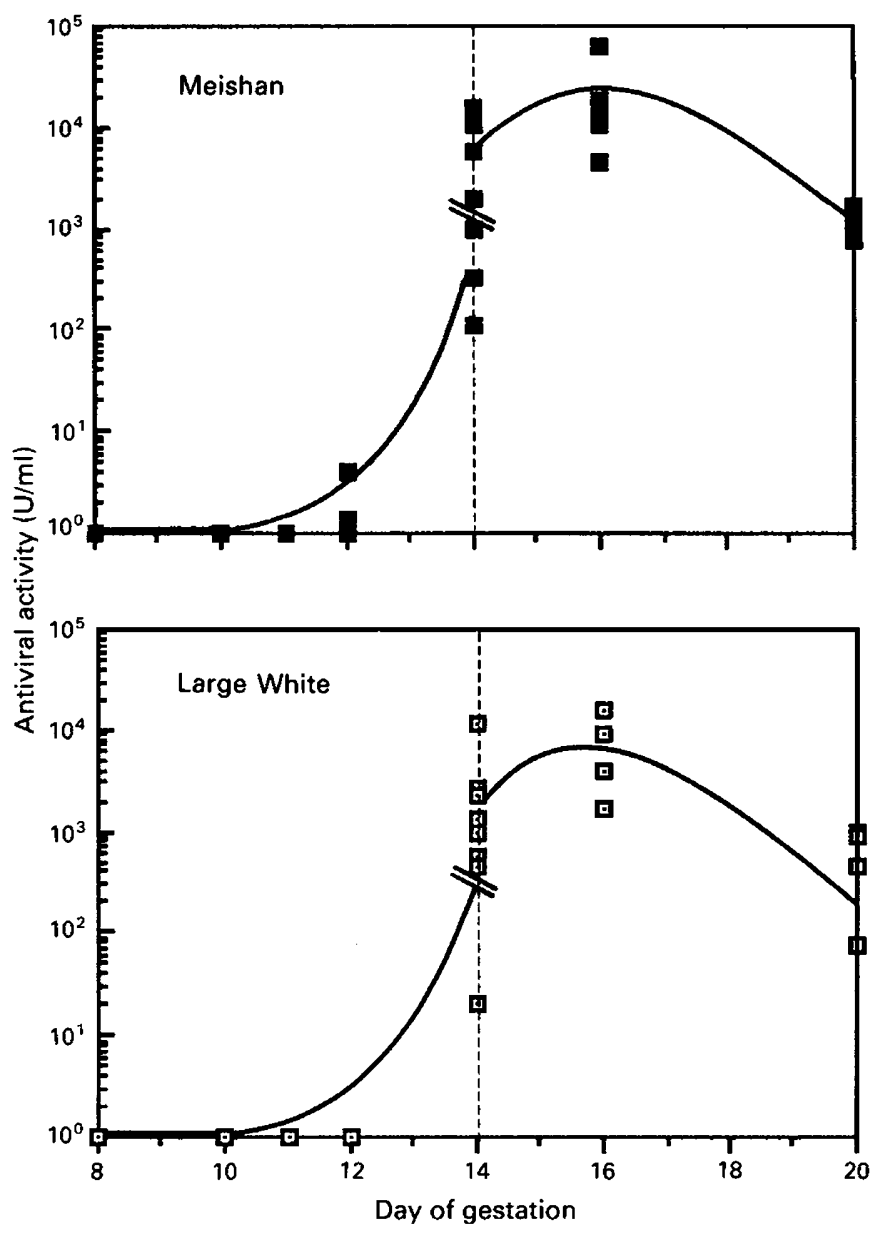

Fig. 1. Antiviral activity (MDBK cells + VSV) in uterine flushings on Days 8 to 20 of pregnancy in gilts of two genotypes, Meishan and Large White. Data from Exp. I (Days 8-14) and Exp. II (Days 14-20) are shown separately to take into account the lower IFN titres from Exp. I. Flushings with no antiviral activity were all scored as $10^{\circ}$. Each square (black or empty) is representative of several gilts, as follows: Meishan gilts were 6, 5 and 4 at Days 8, 10 and 12, respectively, and Large White gilts were 2, 5, 3 and 4 at Days 8, 10,11 and 12, respectively. Corresponding values for Exp. II are given in Table 1.

$(P<0.05)$ and Large White ${ }^{\mathrm{H}}(P<0.001)$ gilts. But at Day 20 titres for Large White ${ }^{\mathrm{H}}$ gilts were higher than for Meishan $(P<0.05)$ and Large White $(P<0.001)$ gilts. Finally, the decrease in antiviral activities in flushings from Large White and Meishan gilts between Days 16 and 20 was significant $(P<0.01$ and $P<0.001$, respectively). Uterine flushings from all gilts, without exception, contained IFN activity. The antiviral activities were quite high, i.e. $10000-20000 \mathrm{IU} / \mathrm{ml}$ between Days 14 and 16 of gestation. The uterine flushing from one Meishan gilt contained $61000 \mathrm{IU} / \mathrm{ml}$, or a total of about $1200000 \mathrm{IU}$ in that uterine horn.

\section{Antiviral activity in conceptus culture medium}

In Exp. II, conceptuses from 32 pregnant gilts, representing the 3 breeds, were cultured (Table 2). In 12-ml cultures, total activities secreted per conceptus between Days 14 and 20 ranged from 
Table 1. Total antiviral activities ( $\log _{10}$ units) in uterine flushings of three genotypes of gilts (Exp. II)

\begin{tabular}{lccc}
\hline & \multicolumn{3}{c}{ Day of gestation } \\
\cline { 2 - 4 } Genotype & 14 & 16 & 20 \\
\hline Meishan & $5.18 \pm 0.45(5)$ & $5.46 \pm 0.51(5)$ & $4.53 \pm 0.15(6)$ \\
Large White & $4.57 \pm 0.55(6)$ & $5.09 \pm 0.46(5)$ & $4.08 \pm 0.82(4)$ \\
Large White $^{\mathrm{H}}$ & $4.07 \pm 0.43(6)$ & $4.96 \pm 0.49(6)$ & $5.03 \pm 0.3(5)$ \\
\hline
\end{tabular}

Values are mean \pm s.e.m. for the number of gilts in parentheses.

10000 to 100000 units, i.e. slightly less than total activities in uterine flushings. On Days 14,16 and 20 (2-4 gilts per group) breed differences in activities were not detected. Nevertheless, unlike in uterine flushings, mean activities tended to be higher in Large White conceptus-conditioned culture medium. Titres were highest in culture medium containing Day-16 conceptuses (all 3 genotypes), then decreased to Day 20. As for uterine flushings, the decrease in titres at Day 20 compared to Days 14 and 16 was significant $(P<0.05)$ for Meishan and Large White conceptuses. Conceptuses from Meishan gilts slaughtered on Days 22 ( 3 conceptuses) and $25(\mathrm{~N}=2)$ were cultured, but less than 100 units of IFN activity were detected, compared with 100000 units of activity on Day 16.

Table 2. Total antiviral activities ( $\log _{10}$ units) in conceptus-conditioned culture medium after $24 \mathrm{~h}$ (Exp. II)

\begin{tabular}{lccccccc}
\hline & \multicolumn{7}{c}{ Day of gestation } \\
\cline { 2 - 8 } Genotype & 14 & 16 & 17 & 19 & 20 & 22 & 25 \\
\hline Meishan & $4.71 \pm 0.69$ & $4.95 \pm 0.6$ & 4.15 & 4.2 & $3.6 \pm 0.00$ & $1.93^{*}$ & $1.8 \dagger$ \\
& $(3)$ & $(3)$ & $(2)$ & $(1)$ & $(3)$ & $(1)$ & $(1)$ \\
Large White & $5.06 \pm 1.4$ & $5.31 \pm 0.61$ & nd & nd & $4.06 \pm 0.78$ & nd & nd \\
& $(3)$ & $(3)$ & & & $(3)$ & & \\
Large White & 4.2 & $4.56 \pm 0.42$ & nd & nd & $3.88 \pm 2.05$ & nd & nd \\
& $(2)$ & $(4)$ & & & $(3)$ & & \\
\hline
\end{tabular}

Values are mean \pm s.e.m. for the number of gilts in parentheses; $n d=$ not determined.

*Average of 3 conceptuses from the same gilt.

†Average of 2 conceptuses from the same gilt.

\section{Characterization of interferon}

The measure of relative antiviral activities on a panel of cells from various species is one means to characterize and to differentiate several types of interferons (Hayes et al., 1979). Table 3 shows that the antiviral activity present in a pooled sample of uterine flushings from Large White gilts differs from that of two species of pig IFN- $\alpha$, the natural leucocyte IFN, and the recombinant subtype rIFN- $\alpha 1$, by 2 main criteria. First, the relative activity on human cells was very low $(0.26 \%$ of activity on MDBK cells) compared to PoIFN-Le (6.4\%) and to rPoIFN- $\alpha 1$ (3.5\%). Secondly, a difference appeared when cytocidal effect on pig kidney cells was tested. It has been reported that cultures of primary or low-passage key kidney cells are extremely sensitive to a cytotoxic effect induced by various IFN- $\alpha$ and virus-induced leucocyte IFNs (Laude \& La Bonnardière, 1984). Conceptus IFN was toxic to such a pig primary kidney cell strain (RPA cells) at a titre (reverse of limit dilution) equivalent to $110 \%$ of the antiviral activity on MDBK cells (Table 3). Corresponding data for PoIFN-Le and rPoIFN- $\alpha 1$ were $0.4 \%$ and $0.9 \%$, respectively. 
Table 3. Cross-species antiviral activities $\left(\log _{10} \mathrm{IU} / \mathrm{ml}\right)$ in uterine flushings from Large White gilts

\begin{tabular}{|c|c|c|c|c|c|c|}
\hline \multirow[b]{3}{*}{ IFNs } & \multicolumn{6}{|c|}{ Cell lines (species) } \\
\hline & \multirow{2}{*}{$\begin{array}{l}\text { MDBK } \\
\text { (cattle) }\end{array}$} & \multirow{2}{*}{$\begin{array}{l}\text { MM10 } \\
\text { (sheep) }\end{array}$} & \multirow{2}{*}{$\begin{array}{c}\text { WISH } \\
\text { (human) }\end{array}$} & \multirow{2}{*}{$\begin{array}{c}\text { L929 } \\
\text { (mouse) }\end{array}$} & \multicolumn{2}{|c|}{$\mathrm{RPa}$ (pig) } \\
\hline & & & & & AVE* & $\mathrm{CCE} \dagger$ \\
\hline Uterine flushings & $3 \cdot 6$ & $\begin{array}{c}3 \cdot 7 \\
(110) \ddagger\end{array}$ & $\begin{array}{l}1 \cdot 0 \\
(0 \cdot 26)\end{array}$ & $\begin{array}{l}<1.6 \\
(0.8)\end{array}$ & $\begin{array}{l}<3.95 \\
(190)\end{array}$ & $\begin{array}{r}3 \cdot 7 \\
(110)\end{array}$ \\
\hline $\begin{array}{l}\text { porIFN-le } \\
\text { (natural) }\end{array}$ & 3 & $\begin{array}{r}3 \cdot 2 \\
(170)\end{array}$ & $\begin{array}{c}1 \cdot 8 \\
(6 \cdot 4)\end{array}$ & $\begin{array}{l}2 \cdot 3 \\
(19)\end{array}$ & $\begin{array}{r}2 \cdot 5 \\
(33)\end{array}$ & $\begin{array}{c}0 \cdot 6 \\
(0 \cdot 4)\end{array}$ \\
\hline $\begin{array}{l}\text { porIFN- } \alpha 1 \\
\text { (recombinant) }\end{array}$ & $4 \cdot 1$ & $\begin{array}{r}4 \cdot 5 \\
(280)\end{array}$ & $\begin{array}{r}1.95 \\
(7 \cdot 2)\end{array}$ & $\begin{array}{c}2 \cdot 6 \\
(3 \cdot 5)\end{array}$ & $\begin{array}{r}4 \cdot 2 \\
(125)\end{array}$ & $\begin{array}{c}2.0 \\
(0.9)\end{array}$ \\
\hline
\end{tabular}

*Antiviral effect.

†Cytocidal effect. Data are presented as $\log$ (units $/ \mathrm{ml}$ ), as for antiviral effect. They represent the reverse of the highest IFN dilution inducing a toxic effect on RPa cells. The usual calibration with international standard IFN was done.

$\ddagger$ Figures in parentheses are \% of IFN titre on MDBK cells.

The antiviral activity from Large White flushings was sensitive to $\mathrm{pH} 2.0$ (after a 24-h dialysis), slightly less than pure recombinant pig IFN- $\gamma$. PoIFN- $\alpha 1$ was completely resistant to this treatment (Table 4).

Table 4. Acid pH stability of uterine antiviral activity from Large White gilts

\begin{tabular}{lrrc}
\hline & \multicolumn{3}{c}{ Activity after treatment (U/ml) } \\
\cline { 2 - 4 } IFN & pH 7.4 & pH 2 & $\begin{array}{c}\text { Residual activity } \\
(\%)^{*}\end{array}$ \\
\hline rPoIFN- $\alpha 1$ & 27000 & 27000 & 100 \\
rPoIFN- $\gamma$ & 5200 & 960 & 18 \\
Flushing & 5200 & 1260 & 24 \\
\hline
\end{tabular}

${ }^{*} \mathrm{U} / \mathrm{ml}$ at $\mathrm{pH} 2: \mathrm{U} / \mathrm{ml}$ at $\mathrm{pH} 7.4 \times 100$.

Antigenicity is another important criterion to characterize an interferon. Antiviral activities in individual flushings and in conceptus culture medium from Day-16 samples were measured in neutralization tests using antisera to IFN- $\alpha$ and IFN- $\gamma$ (see Materials \& Methods). Table 5 shows the results obtained with Large White flushings. Surprisingly, both antisera were individually able to neutralize to some extent the antiviral activity. Moreover, a mixture of the two antibodies, each at the same concentration, brought about nearly complete neutralization of the bioactivity, suggesting that conceptus-derived IFN is a mixture of IFN- $\alpha$ (like) and IFN- $\gamma$ (like) proteins. Also, these data suggest that the proportion of IFN- $\gamma$ is relatively higher in conceptus cultures than in uterine flushings. The same results, not presented here, were obtained with flushings from Meishan gilts.

Finally, the same neutralization assay using rabbit antiserum to ovine trophoblastin was totally negative (data not shown).

\section{Discussion}

High antiviral activities were detected in uterine flushings from all gilts between Days 14 and 20 of gestation and correspondingly elevated in conceptus conditioned culture medium from the same 
Table 5. Seroneutralization of antiviral activity in uterine flushings and conceptus conditioned medium from Large White gilts

\begin{tabular}{lccc}
\hline & \multicolumn{3}{c}{ Antibodies to: } \\
\cline { 2 - 4 } Fluid & IFN- $\alpha$ & PoIFN- $\gamma$ & Both \\
\hline Flushing $(n=5)$ & $1 \cdot 01 \pm 0.32^{*}$ & $1 \cdot 04 \pm 0.24$ & $2 \cdot 74 \pm 0.48$ \\
Medium $(n=5)$ & $0.44 \pm 0.25$ & $1 \cdot 14 \pm 0.29$ & $2 \cdot 46 \pm 0.40$ \\
\hline *Antiviral titre difference $\left(\log _{10}\right)$ between control and seroneutralized \\
$\begin{array}{l}\text { samples (mean } \pm \text { s.e.m of } 5 \text { individual seroneutralizations). All } \\
\text { samples were collected at Day } 16 \text { of gestation. }\end{array}$
\end{tabular}

(or corresponding) pregnant gilts. The levels of activity in the present study were higher than reported by Cross \& Roberts (1989). We cannot explain the nearly 20 -fold difference between their results and the present results, at least in Exp. II, in which samples were assayed 1-2 weeks after collection. The difference is even more pronounced for the IFN titres in conceptus culture medium. One possible reason might be that all culture media in the present work contained the protease inhibitor aprotinin, which was shown by Beers et al. (1990) to protect antiviral activity from degradation. This partly invalidates the statement that conceptuses in culture produce far less activity $(0 \cdot 1-0 \cdot 01 \%)$ than in vivo (Cross \& Roberts, 1989). However, Day-16 sheep conceptuses do secrete 50-100-fold more interferon than do Day-16 pig conceptuses on a per g conceptus wet weight basis (Pontzer et al., 1988). Nevertheless, considering the low titres obtained in Exp. I (Fig. 1), we confirm previous reports of the lability of pig conceptus interferons.

In the present experiments, maximum antiviral activity in uterine flushings was obtained at Day 16, although titres from Days 14 and 16 differed significantly only for Large White ${ }^{\mathrm{H}}$ gilts. The similarity in timing of IFN activities in flushings and culture medium suggests that the Day-16 peak titre corresponds to the day of maximum potential for synthesis and not to an accumulation of IFN in the uterine lumen. As judged by quite low IFN titres on Days 22 and 25 in Meishan conceptus cultures, the major period of IFN synthesis was between Days 14 and 20. If present results are compared with those for ovine trophoblastin (Roberts, 1989), pig interferon activity seems to appear and to peak on about the same days. In sheep, oTP-1 synthesis followed by quantifying specific mRNA from conceptuses in culture (Farin et al., 1989) was found to peak at Day 13, but one cannot exclude that a time shift occurs in the kinetics of activity due to artificial conditions of conceptus cultures.

The only significant difference between Meishan versus Large White and Large White ${ }^{\mathrm{H}}$ gilts was higher activity in Meishan flushings on Day 14. Ideally, not only total activities per uterine horn, but those per $\mathrm{g}$ conceptus should be analysed for more accurate comparison between breeds, but the flushing procedure did not allow counting or weighing of the conceptuses. This difference was not true at Day 16. Therefore, Meishan uterine fluid can be considered to be more active around Day 14 which is the time of attachment (Geisert et al., 1982b). At Day 14, conceptuses from all Large White and Meishan gilts are elongated (Bazer et al., 1988). Therefore, regarding a possible effect of interferon upon conceptus elongation, differences in initial amounts of activity produced at Days 11 or 12 should be considered. In this respect, data from Exp. I, because they are not amenable to rigorous statistical analysis, do not permit a conclusion of earlier secretion by gils of the Meishan breed. IFN activities in conceptus culture medium were not affected by breed, regardless of day of gestation, although maintenance of conceptuses in culture medium is in some ways an artefactual situation, as stated by Cross \& Roberts (1989).

The nature of components with antiviral activity present in uterine flushings and conceptus culture medium is complex. In the present work, two different IFNs were identified on the basis of bioactivity and antigenicity. As it was not possible to isolate and/or purify each component, our 
arguments in favour of the existence of two IFN species are indirect, but they are 3-fold. (i) We found a partial neutralization by each of two antisera, one towards IFN- $\alpha$, and the other antiPoIFN- $\gamma$. Moreover, the level of neutralization was much increased when both antibodies were mixed (Table 5). (ii) The uterine antiviral activity was clearly different from IFN- $\alpha$ by its spectrum of bioactivity on different cells, and in particular it exerted a much more pronounced toxic effect on primary pig kidney cells than did either IFN- $\alpha$ (Table 5). In fact, we found that uterine flushings were intermediate in toxicity between IFN- $\alpha$ and IFN- $\gamma$ (not shown). (iii) Antiviral activity in uterine flushings was very sensitive to $\mathrm{pH} 2 \cdot 0$, much like recombinant IFN- $\gamma$ (Table 4). The lability of gamma or immune IFNs is well documented (for a review, see De Maeyer \& De Maeyer-Guignard, 1988).

Cross \& Roberts (1989) have shown that the antiviral activity found in flushings from pregnant gilts was unstable upon storage and labile at $\mathrm{pH} 4 \cdot 5$. On the other hand, they found that, after electrophoresis of uterine proteins, at least one band with an $M_{\mathrm{r}}$ of 22000 was immunodetected by antiserum to HuIFN- $\alpha$. This protein was absent in uterine flushings from cyclic gilts. Taken together, their results might be accounted for by the properties of a mixture of IFNs of the alpha and gamma types.

More detailed characterization of each of these antiviral activities is needed. All interferon species found and characterized so far in early pregnancy in ruminants are related, but not identical, to IFN-as of class II (Imakawa et al., 1989). One paradoxical property of pig conceptus antiviral activity is that it is partly neutralized by immunoglobulins to human leucocyte IFN (Table 5) but not at all by an antiserum to oTP-1 (not shown). By analogy with the results and hypothesis of Adolf (1987), one cannot exclude the existence of a third sub-class of alpha-related genes, expressed also in induced leucocytes, and to which the pig alpha-like conceptus-derived IFN could belong. On the basis of seroneutralization data, the relative amounts of the two IFN species seem to be different in vivo and in vitro, which suggests either that conceptus synthesis is in some way regulated by the maternal environment, or that the activity of IFN- $\alpha$-like species could be less stable than that of IFN- $\gamma$. Further characterization of the activity of IFN- $\gamma$ and identification of cells secreting it are needed, but the possibility that IFN- $\gamma$ is secreted by the pig conceptus early in gestation raises several questions. As far as is currently known, IFN- $\gamma$ is a lymphokine produced by $\mathrm{T}$ lymphocytes (Stobo et al., 1974). At the stages of conceptus development studied here, no lymphoid cells in conceptuses have ever been reported. One must, therefore, suppose that embryonic or trophoblastic cells are the source of this activity; this will have to be established.

Previous publications have stressed the difference between the pig and ruminants as to the role(s) that IFN(s) could pay during gestation (Bazer et al., 1989), as in-vivo infusion experiments seem to rule out an effect of conceptus proteins on corpus luteum lifespan (Harney \& Bazer, 1989). The discovery of uterine IFN- $\gamma$ might suggest an additional role(s) to those previously found or supposed (for a review, see De Maeyer \& De Maeyer-Guignard, 1988); among them are the stimulation of antigens of the major histocompatability complex at critical steps of the immune recognition by the mother (Feinman et al., 1987), or an effect on the differentiation of embryonic or other cells (Honda \& Rostami, 1989). IFN- $\gamma$ could also exert a protective effect on the conceptus against maternal immune lysis (Renkonen et al., 1988). Determination of the target tissue(s) of the two IFNs $(\alpha$ and $\gamma$ ) found during pregnancy in the pig will be one of the conditions needed before one can understand their role, individually and/or in synergy. However, in view of the well defined period of secretion reported here, one cannot rule out that interferons, in particular IFN- $\gamma$, play a role in a crucial step in differentiation of the pig conceptus.

We thank Pierre Després who was in charge of the pig experimental unit, and Robert Procureur for help with surgery and collection of samples (Physiologie de la Reproduction, INRA, Centre de Tours); Christiane De Vaureix for carrying out interferon assays; and Charles Carrat for help in statistical analysis (Laboratoire de Virologie et de d'Immunologie, INRA, Jouy-en-Josas). 


\section{References}

Adolf, G.R. (1987) Antigenic structure of human interferon $\omega 1$ (interferon $\mathrm{a}_{\mathrm{II}} 1$ ); comparison with other human interferons. J. gen. Virol. 68, 1669-1676.

Bazer, F.W., Vallet, J.L., Ashworth, C.J., Anthony, R.V. \& Roberts, R.M. (1987) The role of ovine conceptus secretory proteins in the establishment of pregnancy. In Cell and Molecular Biology of the Uterus, pp. 221231. Ed. W. W. Leavitt. Plenum Press, New York.

Bazer, F.W., Thatcher, W.W., Martinat-Botte, F. \& Terqui, M. (1988) Conceptus development in large while and prolific Chinese Meishan pigs. J. Reprod. Fert. 84, 37-42.

Bazer, F.W., Vallet, J.L., Gross, T.S. \& Thatcher, W.W. (1989) Comparative aspects of maternal recognition of pregnancy between sheep and pigs. J. Reprod. Fert., Suppl. 37, 85-89.

Beers, S., Mirando, M.A., Pontzer, C.H., Harney, J.P., Torres, B.A., Johnson, H.M. \& Bazer, F.W. (1990) Influence of the endometrium, protease inhibitors and freezing on antiviral activity of proteins secreted by pig conceptuses. $J$. Reprod. Fert. 88, 205-211.

Bolet, G., Martinat-Botte, F., Locatelli, P., Gruand, J., Terqui, M. \& Berthelot, F. (1986) Components of prolificacy of hyperprolific Large White sows. Comparison with Meishan and control Large White sows. Genet. Sel. Evol. 18, 333-342.

Chaouat, G., Kiger, N. \& Wegmann, T.G. (1983) Vaccination against spontaneous abortion in mice. $J$. Reprod. Immunol. 4, 389-392.

Charley, B., McCullough, K. \& Martinod, S. (1988) Antiviral and antigenic properties of recombinant porcine interferon gamma. Vet. Immunol. Immunopathol. 19, 95-103.

Charlier, M., Hue, D., Martal, J. \& Gaye, P. (1989) Cloning and expression of cDNA encoding ovine trophoblastin: its identity with a class-II alpha interferon. Gene 77, 341-348.

Charpigny, G., Reinaud, P., Huet, J.-C., Guillomot, M., Charlier, M., Pernollet, J.-C. \& Martal, J. (1988) High homology between a trophoblastic protein (trophoblastin) isolated from ovine embryo and $\alpha$ interferons. FEBS Lett. 228, 12-16.

Cross, J.C. \& Roberts, R.M. (1989) Porcine conceptuses secrete an interferon during the preattachment period of early pregnancy. Biol. Reprod. 40, 1109-1118.

De Maeyer, E. \& De Maeyer-Guignard, J. (1988) Interferons as multifunctional gene activators. In Interferons and Other Regulatory Cytokines, pp. 91-113. John Wiley \& Sons, New York.

Farin, C.E., Imakawa, K. \& Roberts, R.M. (1989) In situ localization of mRNA for the interferon, Ovine Trophoblast Protein-1, during early embryonic development of the sheep. Molec. Endocrinol. 3, 1099-1107.

Feinman, M.A., Kliman, H.J. \& Main, E.K. (1987) HLA antigen expression and induction by gammainterferon in cultured human trophoblasts. Am. J. Obstet. Gynecol. 157, 1429-1434.

Geisert, R.D., Renegar, H., Thatcher, W.W., Roberts, R.M. \& Bazer, F.W. (1982a) Establishment of pregnancy in the pig. I. Interrelationships between preimplantation development of the pig blastocyst and uterine endometrial secretions. Biol. Reprod. 27, 925-939.

Geisert, R.D., Brookbank, J.W., Roberts, R.M. \& Bazer, F.W. (1982b). Establishment of pregnancy in the pig: II. Cellular remodeling of the porcine trophoblast during elongation on Day 12 of pregnancy. Biol. Reprod. 27, 941-955.

Gill, T.J., III (1983) Immunogenetics of spontaneous abortions in humans. Transplantation 35, 1-6.

Harney, J.P. \& Bazer, F.W. (1989) Effect of porcine conceptus secretory proteins on interestrous interval and uterine secretion of prostaglandins. Biol. Reprod. 41, 277-284.

Hayes, T.G., Yip, Y.K. \& Vilcek, J. (1979) Interferon production by Human fibroblasts. Virology 98, 351-363.

Helmer, S.D., Hansen, P.J., Thatcher, W.W., Johnson, J.W. \& Bazer, F.W. (1988) Intrauterine infusion of purified bovine trophoblast protein-1 (bTP-1) extends corpus luteum (CL) lifespan in cyclic cattle. J. Anim. Sci. 66 (Suppl. 1), 415, abstr.

Heyman, Y., Camous, S., Fèvre, J., Méziou, W. \& Martal, J. (1984) Maintenance of the corpus luteum after uterine transfer of trophoblastic vesicles to cyclic cows and ewes. J. Reprod. Fert. 70, 533-540.

Honda, H. \& Rostami, A. (1989) Expression of major histocompatibility complex class I antigens in rat muscle cultures: the possible developmental role in myogenesis. Proc.natn. Acad. Sci. USA 86, 7007-7011.

Hunt, J.S. (1989) Cytokine networks in the uteroplacental unit: macrophages as pivotal regulatory cells. $J$. Reprod. Immunol. 16, 1-17.

Hunziker, R.D. \& Wegmann, T.G. (1986) Placental immunoregulation. CRC Critical Reviews in Immunology 6, 245-285.

Imakawa, K., Anthony, R.V., Kazemi, M., Marotti, K.R., Polites, H.G. \& Roberts, R.M. (1987) Interferonlike sequence of ovine trophoblast protein secreted by embryonic trophectoderm. Nature, Lond. 330, 377-379.

Imakawa, K., Hansen, T.R., Malathy, P.-V., Anthony, R.V., Polites, H.G., Marotti, K.R. \& Roberts, R.M. (1989) Molecular cloning and characterization of 3 complementary deoxyribonucleic acids corresponding to bovine trophoblast protein-1: a comparison with ovine trophoblast protein-1 and bovine interferon $\alpha$ II. Molec. Endocrinol. 3, 127-139.

Kawade, Y. \& Watanabe, Y. (1984) Neutralization of interferon by antibody: appraisals of methods of determining and expressing the neutralisation titer. $J$. Interferon Res. 4, 571-584.

La Bonnardière, C. \& Laude H. (1981) High interferon titer in newborn pig intestine during experimentally induced viral enteritis. Infect. Immun. 32, 28-31.

Laude, H. \& La Bonnardière, C. (1984) Cytocidal effect of interferons on porcine renal cells. J. Interferon Res. 4, 101-110.

Martal, J., Lacroix, M.-C., Loudes, C., Saunier, M. \& Wintenberger-Torres, S.R. (1979) Trophoblastin, an antiluteolytic protein present in early pregnancy in sheep. J. Reprod. Fert. 56, 63-73.

Mirando, M.A., Harney, J.P., Beers, S., Pontzer, C.H., Torres, B.A., Johnson, H.M. \& Bazer, F.W. (1990) 
Onset of secretion of proteins with antiviral activity by pig conceptuses. J. Reprod. Fert. 88, 197-203.

Pontzer, C.H., Torres, B.A., Vallet, J.L., Bazer, F.W. \& Johnson, H.M. (1988) Antiviral activity of the pregnancy recognition hormone ovine trophoblast protein-1. Biochem. Biophys. Res. Commun. 152, 801-807.

Renkonen, A.R., Ristimäki, A. \& Häyry, P. (1988) Interferon-gamma protects human endothelial cells from lymphokine-activated killer cell-mediated lysis. Eur. J. Immunol. 18, 1839-1842.

Roberts, R.M. (1989) A novel group of interferons associated with the early ovine and bovine embryo. $J$. Interferon Res. 9, 373-378.

Stewart, H.J., McCann, S.H.E., Northrop, A.J., Lamming, G.E. \& Flint, A.P.F. (1989) Sheep antiluteolytic interferon: cDNA sequence and analysis of mRNA levels. J. molec. Endocrinol. 2, 65-70.
Stobo, J., Green, I., Jackson, L. \& Baron, S. (1974) Identification of a subpopulation of mouse lymphoïd cells required for interferon production after stimulation with mitogens. J. Immunol. 112, 1589-1593.

Terqui, M., Bazer, F.W. \& Martinat-Botte, F. (1990) Quels sont les mécanismes responsables de la prolificité de la race Meishan? In Proc. Chinese Pig Symposium, Toulouse, pp. 19-32. Eds M. Molenat and C. Legault. Institut National de la Recherche Agronomique, Paris.

Vallet, J.L., Bazer, F.W., Fliss, M.F.V. \& Thatcher, W.W. (1988) Effect of ovine conceptus secretory proteins and purified ovine trophoblast protein- 1 on interoestrous interval and plasma concentrations of prostaglandins F-2 $\alpha$ and $\mathrm{E}$ and 13,14-dihydro-15keto-prostaglandin F-2 $\alpha$ in cyclic ewes. $J$. Reprod. Fert. 84, 493-504.

Received 17 May 1990 